\title{
Factors that influence pig production in Central Uganda - Case study of Nangabo Sub-County, Wakiso district
}

\author{
Dennis Muhanguzi, Vincent Lutwama, Frank Norbert Mwiine \\ Department of Biomolecular Resources and Biolaboratory Sciences, \\ College of Veterinary Medicine, Animal Resources and Biosecurity (COVAB), \\ Makerere University, P.O Box 7062, Kampala-Uganda \\ Corresponding author: Frank Norbert Mwiine, email: fmwiine@gmail.com, fmwiine@yahoo.com \\ Received: 28-11-2011, Accepted: 01-01-2012, Published Online: 10-03-2012 \\ doi: $10.5455 /$ vetworld.2012.346-351
}

\begin{abstract}
Aim: To study the factors affecting pig production in Nangabo Sub-County, Wakiso District, Central Uganda. Materials and Methods: A total of 11\% (1350/12783) of all households in the Nangabo Sub-County kept pigs. The systematic sampling technique was used to complete the list of all pig farming households. This was done by taking $10^{\text {th }}$ farming household until $10 \%$ of all the farming households were sampled. A total of 135 farmers were interviewed with semistructured questionnaire. Questionnaire data was entered into Microsoft Excel worksheet and trans-ferred into Statistical Package for Social Scientists

Results: Results indicated that $49.6 \%$ of the pigs were raised in the semi-intensive system while $31 \%, 12 \%$ and $8 \%$ of the farmers kept pigs on intensive, tethering and free range rearing systems respectively. Farmers that raised their pigs on what is hereby referred to as semi-intensive and intensive management systems allowed their pigs up to five and two hours of open foraging respectively. Ninety eight percent of the farmers provided housing to their pigs and the commonest pig houses were local mud houses and a few of them were tree shades. Majority of farmers $(85.2 \%)$ watered their pigs at least once a day. The major factors limiting pig production were; diseases and parasites mainly helminthosis and African swine fever (ASF). Others included; high costs of inputs, lack of capital, unstable availability of feed resources, inadequate advisory services and feed price fluctuation (maize bran, sow and weaner), lack of good quality breeding stock, poor and unorganized marketing, lack of enough land, high costs of veterinary medicines and inability to keep records. Additionally, lack of enough water and uncontrolled pig movement grossly limited the pig production in Wakiso district. Most Ugandans keep their pigs in periurban areas of Uganda. It was however, noted that there were important limitations for pig production in the country. To improve pig production and reduce animal protein deficit, knowledge on constraints to pig production was important to inform pig sector promotion stakeholders.

Conclusion: Limitations to pig farming including parasites and diseases, ASF, nutritional deficiencies, high cost of inputs like building materials, drugs and veterinary services, inadequate capital and failure of farmers to access credit services, expensive feeds among others were identified and should be addressed to meet national animal protein requirements.
\end{abstract}

Key words: Factors limiting pig production, Nangabo Sub County, Pig breeds, Pig rearing systems

To cite this article :

Muhanguzi D, Lutwama V, Mwiine FN (2012) Factors that influence pig production in Central Uganda - Case study of Nangabo Sub-County, Wakiso district, Vet World 5(6): 346-351, doi: 10.5455/vetworld.2012.346-351

\section{Introduction}

Since 1971 the volume of pork consumed has steadily increased in developing and developed countries. This increase has been remarkably (up to $70 \%$ ) high in developing countries [1,2]. As a result pork has recently been quoted to be the most popular source of animal protein in the world [1]. The World Health organization (WHO) report for developing countries indicates that there is a very big deficit in the supply of animal protein with 6.1 million Ugandans malnourished and $40 \%$ of children deaths below the age of five due to malnourishment [3]. A well managed pig industry would bridge such glaring animal protein deficit. This is especially so because of pigs' high fecundity rate, high feed conversion efficiency, early maturity, short generation interval, relatively small space requirement and their ability to produce maximally under varied management systems without sophisticated biosafety measures [4].

The government of Uganda under the poverty eradication plan (PEAP) and the modernization of Agriculture through National Agricultural Advisory Services (NAADS) framework has recently been promoting the pig industry having realized its potential for poverty eradication and quick animal protein provision to the most disadvantaged communities of 
Factors that influence pig production in Central Uganda - Case study of Nangabo Sub-County, Wakiso district

Table-1. Farmer distribution by age and education level

\begin{tabular}{lcl|lrl}
\hline $\begin{array}{l}\text { Age (Years ) } \\
\text { Group }\end{array}$ & Number interviewed & $\begin{array}{l}\text { Education } \\
\text { Level }\end{array}$ & $\begin{array}{l}\text { Number interviewed } \\
\text { confidence interval) }\end{array}$ & $\begin{array}{l}\text { Percentage (95\% } \\
\text { confidence interval) }\end{array}$ \\
\hline$<23$ & 8 & $5.9(4.26-7.50)$ & < Primary level & 32 & $23.7(22.4-25)$ \\
$24-33$ & 31 & $23.0(21.5-24.5)$ & Secondary level & 47 & $34.8(33.4-36.2)$ \\
$34-43$ & 49 & $36.3(34.6-37.4)$ & > Secondary & 56 & $41.5(40.2-42.8)$ \\
$>43$ & 47 & $34.8(33.4-36.2)$ & Total & 135 & 100.0 \\
Total & 135 & 100.0 & & & \\
\hline
\end{tabular}

Uganda. Despite these efforts, Uganda's livestock sector grows at a dismal rate of $4 \%$ with only 3.2 million pigs in the whole country of approximately 33 million people [5]. Most of these pigs are kept around towns in central Uganda.

We therefore set out to explore some of the factors that farmers considered as the most important limitations for pig production in a typical peri-urban environment where most Ugandan pigs are kept. Such knowledge is deemed important in informing pig sector promotion actors in order to improve pig production and reduce animal protein deficit.

\section{Materials and Methods}

Study area: This study was carried out in Wakiso district located in central Uganda. The district surrounds Kampala, the capital of Uganda, and boarders Mukono in the East, Mubende and Mpigi districts in the West, Luwero district in the North and Kalangala district in the South. Formerly part of Mpigi District, it came into existence in 2000, when the 3 counties of Mpigi DistrictBusiro, Kyaddondo and Entebbe Municipality became Wakiso District. Nangabo Sub-County is located in Kyaddondo County and is made up of ten villages with a population of 55,751 people in about 12,783 households, about $15 \mathrm{Km}$ from the centre of Kampala [6]. About 11\% (1350/12783) households in Nangabo Sub County keep pigs [5]. The number of pig owning households in Wakiso District has recently been reported by the Uganda National Bureau of Statistics (UBOS) to have increased to $16 \%$ [7].

Sampling flame and sampling strategy: A complete list of pig farming households was obtained from Nangabo Sub-county. A total of 11\% (1350/12783) of households in the Sub-county kept pigs. Systematic sampling technique was used to complete the list of all pig farming households. This was done by taking the $10^{\text {th }}$ farming household until $10 \%$ of all the farming households were sampled.

Respondent interviews, observation and physical inspection of house holds: To understand the factors that limited pig production in Nangabo subcounty,
Wakiso District, Central Uganda, we administered a semi-structured questionnaire designed to capture limitations that had previously been raised in central districts Veterinary officers' workshop on pig production in central Uganda. The questionnaire was pre-tested before use to improve the questions there in and optimise the responses that could be captured upon its use. Participant observations were; pig housing, pig feeding, management system, feed ingredients and other pig farming practices. These observations were compared with questionnaire answers so as to keep them consistent.

Some informal interviews were also carried out to get in-depth understanding of farmers' limitations to pig production especially with regard to parameters such as availability of advisory services, market infrastructure, availability of feed stuffs, feed stuff price fluctuations and micro financing. One hundred and thirty five (135) semi-structured questionnaires were completed by all selected pig keeping households.

Data handling and analysis: Questionnaire data was entered into Microsoft Excel worksheet and transferred into Statistical Package for Social Scientists (SPSS) on the descriptive statistical tools interface and summarised into frequencies and other descriptive parameters. Informal interviews were summarised, transcribed and written up together with semi-structured questionnaire and participant observation data.

\section{Results}

Socio-demographic characteristics of farmers: Questionnaires were administered to 135 farmers, $62 \%(84 / 135)$ of whom were males and $38 \%(51 / 135)$ females. Most of the farmers were above 23 years of age and at least had a Uganda secondary education exposure (Table 1). Of the 135 farmers, $44.4 \%$ were full time farmers, $25.2 \%$ public servants, $22.2 \%$ had other private businesses while $8.1 \%$ were students. $95 \%$ of the pig farmers kept pigs to generate income while $5 \%$ kept pigs for home consumption. Of the $94.8 \% ; 54.8 \%$ marketed piglets, $21.5 \%$ live adult pigs, $15.6 \%$ pork and $8.1 \%$ combinations of pork and 
Factors that influence pig production in Central Uganda - Case study of Nangabo Sub-County, Wakiso district

Table-2. Pig production assesment as expressed as a function of breed and litter size

\begin{tabular}{l|cccc}
\hline \multirow{2}{*}{ Litter size at farrowing } & \multicolumn{4}{|l}{ Type of pigs reared } \\
\cline { 2 - 5 } & $\begin{array}{c}\text { Farms keeping } \\
\text { cross breeds }\end{array}$ & $\begin{array}{c}\text { Farms keeping keeping Exotic } \\
\text { (Landrace/ large white) pigs }\end{array}$ & $\begin{array}{c}\text { Farms keeping } \\
\text { Local breeds }\end{array}$ & $\begin{array}{c}\text { Total number of } \\
\text { farmers }\end{array}$ \\
\hline <6piglets & 15 & 2 & 1 & 18 \\
$6-10$ piglets & 63 & 27 & 4 & 94 \\
>10piglets & 13 & 9 & 1 & 23 \\
Total (Respondents) & 91 & 38 & 6 & 135 \\
\hline
\end{tabular}

Table-3. Pig rearing systems and types of housing

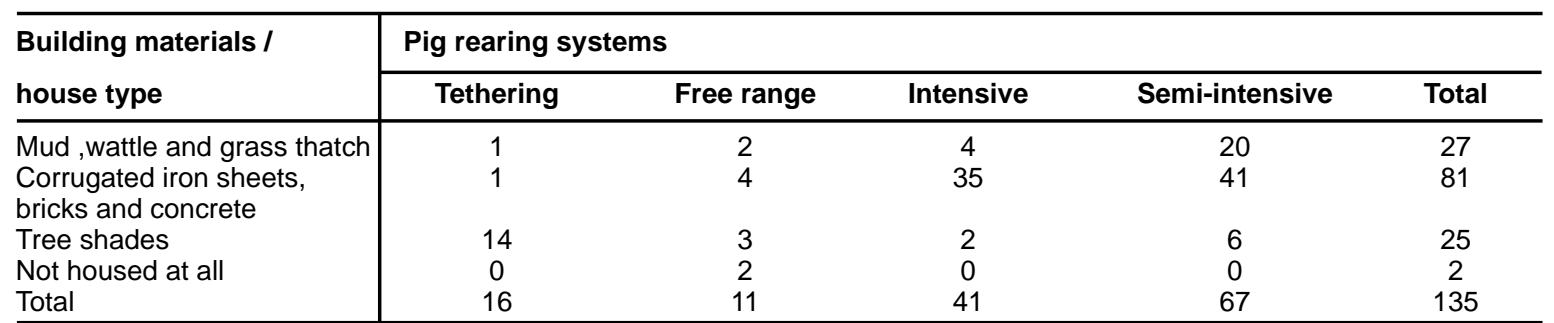

piglets, live adults and pork depending on the market available.

Breed types and production performance measure: As a benchmark of the current production performance of the pig sector in Nangabo Sub County, we observed the current breeds kept and the average litter size at furrowing. The most dominant pig breed type were cross breeds of Local Ugandan breeds with Landrace and large white. Cross breeds constituted $67.4 \%$ of the pigs in the farms visited while farms keeping pure Exotic landrace or large white constituted $28.1 \%, 4.4 \%$ of all the pig farms visited respectively. On average litter size at furrowing for the 135 farms visited were between 6-10 piglets (Table 2 ).

Assessment of pig production systems and limitations to pig production: On average most (96\%) farmers received veterinary services 1-3 times a month. Afew farmers (4\%) consulted veterinary service providers at least once a week.

Seventy five percent (103/135) of the farmers reported to have experienced pig disease challenges while the rest didn't have any disease occurrence problem. Of those who experienced pig disease problems at their farms $58.5 \%$ (57/103) of them, consulted veterinarians for professional help while the rest used local plant extracts (herbs) or did nothing to the sick pigs.

Majority 55\% (74/135) of the farmers got their breeding stock from other farmers. Two percent (3/135) of the farmers got their replacement stock from their own parent stock while $43 \%$ (58/135) got their replacement stock in form of gifts. About 55\% (73/132) of the farmers who got replacement stock from other farms or as gifts isolated them before mixing them with the rest of the herd. Forty five percent (59/132) of the farmers mixed pigs obtained from other sources into their herds right away.

A range of management systems were observed in Nangabo Sub County ranging from tethering to intensive management where commercial feeds were provided and pigs were housed all the time (Table 3 ). Pigs were housed in local mud and wattle houses, tree shades, and conventional tropical pig houses with half sold wall made of bricks, sand and cement with the upper part made of wire mesh and roofed with colligated iron sheets. All pigs were housed in either of the housing types. About 28\% (38/135) of the farmers only kept pigs while $72 \%(97 / 135)$ kept other food animals including goats, poultry and cattle in that order.

The majority of respondents $59 \%(80 / 135)$ fed their pigs on cassava, potatoes and crop residues (sweet potato vines, banana peelings). Twenty four percent of all pig farmers (33/135) fed their pigs grasses like Pennisetum purpureum, Commelina banghalensis, and Biden pilosa while 16\% (22/135) of the farmers fed their pigs on ruminal contents from the local abattoirs. Ninety four percent $(127 / 135)$ of the farmers provided feeds to pigs one to two times a day. Only eight farmers $(6 \%)$ provided their pigs with feeds adlibitum. None of the farmers used only commercial feeds. Eighty seven percent of the interviewed farmers $(115 / 132)$ watered their pigs at least once in a day. Only $15 \%$ (20/135) of the inter-viewed farmers did not provide water for their pigs.

Constraints to pig production: There were several production limitations that were identified by farmers 


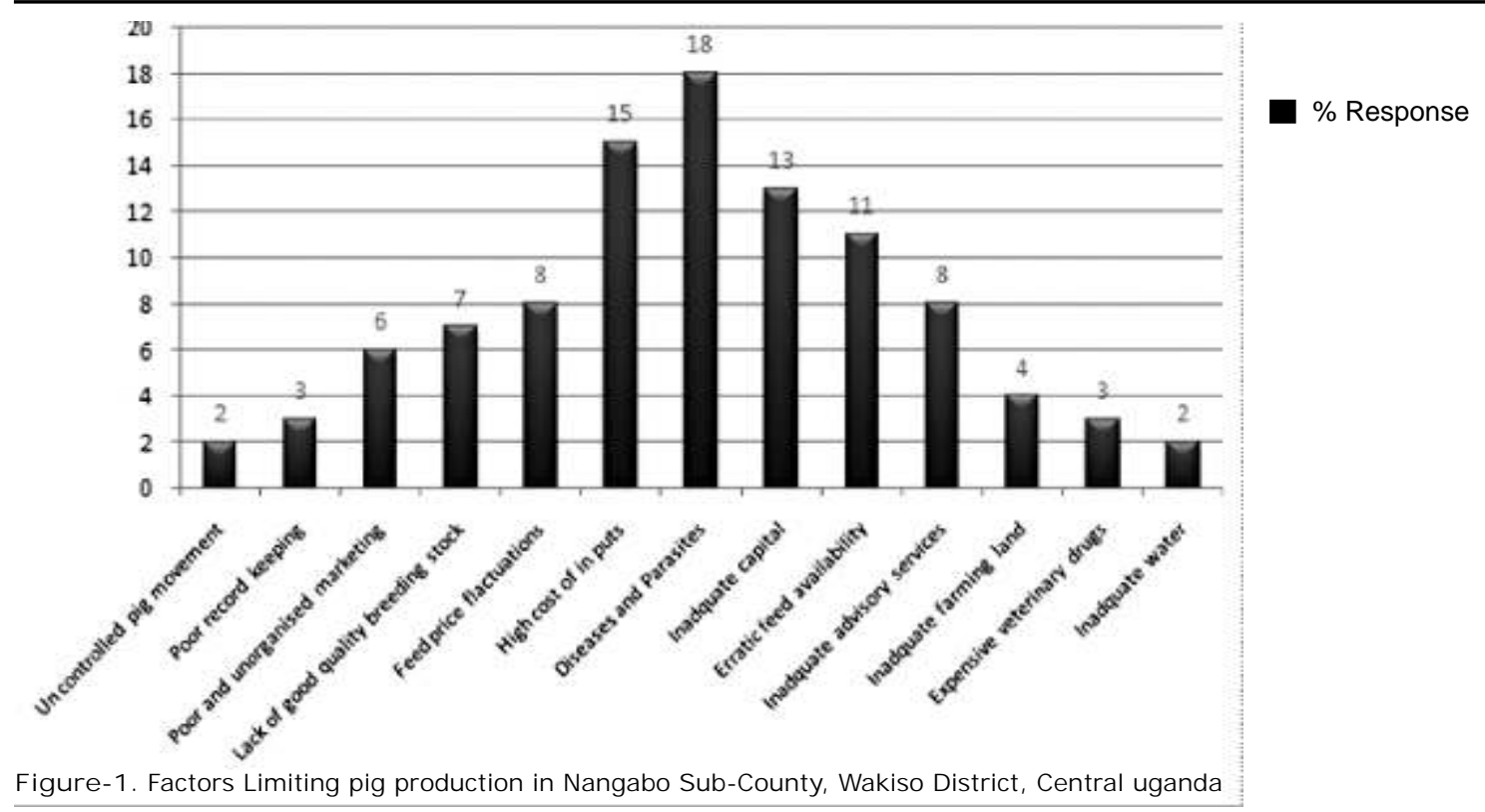

and these parasitic diseases, helminthosis, cysticercosis, African swine fever (ASF) and nutritional deficiencies manifesting as stuntedness and poor growth rates. Contagious diseases like ASF were more of a problem on farms that did not house their pigs implying an association with uncontrolled pig movement while nutritional deficiencies were reported and observed to be a problem on farms that majorly fed their pigs on grasses and other plant residues. Commercial feeds were not used because of the high cost, especially maize bran. Other constraints included high cost of inputs like pig house building materials, drugs and veterinary services, the cost of improved breeds like large white, landrace and Cambrough. Farmers indicated that it was hard for them to access loans from commercial banks since farming was perceived as a high risk business. About 15\% (20/135) of the farmers interviewed did not provide pigs with water because of water scarcity (Figure 1).

\section{Discussion}

Pig production in the tropics has been recommended as a likely solution to animal protein deficiency and as a tool to fighting poverty in the tropics [8]. Uganda Government under the PEAT and NAADS has also been keenly promoting pig production for the same reasons. The limitations to pig production were parasites and diseases, high cost of inputs, inadequate capital input, expensive feeds as a result of erratic feed supply associated with price fluctuation, inadequate advisory services, lack of good quality breeding stock, poor and unorganized marketing, expensive veterinary drugs and uncontrolled pig movement in that order of significance.

In Wakiso district, a sizable population (44.4\%) is involved in pig farming as a full time job. They market live pigs (adults and piglets) or slaughter the pigs and sell pork. The central region pig farmers therefore have a general pig production cycle of buying piglets either to fatten them for sale or to finish them for breeding purposes with the majority (95\%) aiming at generating income. Only $5 \%$ of the farmers kept pigs for home consumption. This was supported by the observation that both sexes and all age groups kept pigs indicated that if limitations to pig production in central region were reduced, the enterprise could be source of employment and livelihood to most of the farmers in central region. Seventy six percent (103/ 135) of the farmers had at least a Uganda certificate of education indicating that there could be quick adoption of better technologies for pig production if different promoters of pig production start promoting good practices in pig production like disease control, housing, feeding and breeding technologies.

Parasites and diseases ranging from helminthes to highly contagious and infectious diseases like African swine fever continue to devastate the pig industry in Africa $[9,10,11]$. The current study indicates that parasites and helminthes were also a problem in Wakiso District, Central Uganda an indication that future plans for improvement of this industry should take care of this problem. One such a strategy to reducing parasites and diseases and enhancing 
productivity would be to improve husbandry practices while harnessing local situation in the affected areas. Improvement of husbandry practices would practically reduce the incidence of most infectious / contagious diseases and helminthes that are spread from scavenging pigs [4].

Unrestricted pig movement was reported as one of the problems the farmers' face in Wakiso district, Uganda and this was linked to the periodic surges in disease out breaks during informal interviews with farmers. The words intensive and semi-intensive management (Table 3) were conservatively used to mean that pigs were housed for more than four hours a day and given supplementary feeding during hours of confinement. Much as we have indicated (Table 3) that up to $80 \%(108 / 135)$ of all the farmers were intensively or semi-intensively managing their pigs, in practice these pigs were let out for two (Intensive) to five (semi-intensive) hours to forage and returned in their pens at night. As such there was no farmer who kept their pigs in total confinement. Therefore, advocating for total pig confinement would reduce the incidence of diseases like African Swine fever, cysticercosis and helminthosis that have for long devastated the African pig industry [4]. The problem of diseases in Wakiso district could be exacerbated by the fact that most farmers $(55 \%$; 74/135) obtained replacement stock from other farms either in form of gifts or bought from such farms and they didn't isolate them before mixing them with the rest of their pig herds.

High cost of inputs like corrugated iron sheets, cement and other building materials were indicated as the reason why not all the farmers had houses for pigs. For this reason other farmers opted to keep their pigs in tree shades, tethered them or built houses out of locally available cheap building materials like reeds, mud and grass thatched them. Unfortunately pigs could easily escape from such enclosures and roam around increasing the likelihood of disease transmission and destruction of crops.

Inadequate capital input was one of the reasons why farmers indicated that they could not afford housing pigs in permanent easy- to -disinfect houses because their capital investment could not afford them such building materials. This was exercabated by the fact that most lending commercial institutions regarded farming as a very high risk business in Uganda making it hard for farmers to access loans. This situation was further complicated by the fact that farmers didn't have collateral investments/property to use to get loans from the microfinance institutions in
Uganda. This was supported by the fact that about $20 \%$ of farmers were not able to access loans.

The bulk of the carbohydrate and protein content of pig and poultry feeds were made from maize, soya bean and fish. Unfortunately, these were also sources of carbohydrate and protein to humans. This would necessitate a big surplus of these ingredients if they are to be incorporated in animal feeds. Contrary there were no such a big surplus of maize, soya bean and fish all the year around that could be incorporated in animal feeds. The animal feed supplies were therefore erratic with highest carbohydrate and protein surpluses available in harvesting season and least available in dry off-harvest seasons. Expensive feeds as a result of erratic feed supply associated with price fluctuation all make pig production a some what expensive venture for the small holder pig farmers not only in Wakiso district but also in other African countries [12].

Feeds are the single most expensive input in pig production in Uganda because pigs compete with humans for maize, soybean and fish as the main sources of carbohydrates and proteins for both humans and pigs. Recent changes in weather conditions characterized by prolonged droughts have resulted in prices for protein and carbohydrate sources for pigs and poultry increasing to up to threefold. In extreme cases the pig industry has seen a complete shortage of protein and carbohydrate sources there by causing some farmers to disband their farms.

The NAADS has taken a fore role in Agricultural advisory service provision in Uganda [13]. Despite this there are still very many areas peri-urban and purely rural which do not have readily available extension workers. This partly due to recent changes in the Agricultural advisory services frame work involving converting of all the Central Agricultural Advisory service providers into NAADS and the uncertainty to their career development and job security associated with the said change. Poor pay that results into these service providers taking on their own private enterprises and devoting less time to agricultural advisory service provision would as well be the other reason why they don't devote all their time to Agricultural service provision. This might explain why despite NAADS services being in place in Wakiso district farmers still don't get adequate agricultural advisory services.

Lack of good quality breeding stock was highlighted as a limitation to pig in Nangabo sub county, Wakiso District. This has also been reported to be a problem to Kenyan pig farmers [14]. The Uganda pig industry largely depends on indigenous breeds 
whose production potential (furrowing rate, litter size, growth rate, and average body size) is comparably lower than that of exotic breeds like large white, Landrace and Cambrough despite the former's comparable high resilience to parasites and diseases. Consequently, small holder farmers' ability to enlarge their enterprises remains poor due to low rates of replacement stock. This requires private and public interventions to provide breeding stock to farmers on subsidized prices.

Poor and unorganized marketing has as well been highlighted to be a limitation to pig production in Kenya [14] as was reported by farmers in Nangabo sub-county, Wakiso District. The livestock product marketing chain in Uganda is characterized by poor slaughter facilities and middle men that buy pigs from farmers at very low prices and sell them to Wambizi traders; the only established pig slaughter house in Kampala, Uganda. Some of them sell them directly to pork serving centers in Kampala city so as to evade taxes (Local government and meat inspection charges) at the slaughter slab. Public and private sector investment in livestock marketing infrastructure is needed to overcome this problem.

Water scarcity was cited as one of the limitations of pig production in Wakiso district. This is the reason why about $15 \%$ (20/135) farmers did not water their pigs at all and why the rest of the farmers watered their pigs just once in a day instead of providing water to the pigs adlibtum as required.

\section{Conclusion}

Pig production is one of the most thought after strategies to reduce animal protein deficit in the tropics. In this regard most countries including Uganda under the NAADS program are now promoting pig production. In this study, we identified that before pig production can be improved, to meet national animal protein requirements and improve farmers' incomes, limitations to pig farming including diseases like helminthes, ASF, nutritional deficiencies, high cost of inputs like building materials, drugs and veterinary services, inadequate capital and failure for farmers to access credit services, expensive feeds among others should be addressed.

\section{Acknowledgements}

We would like to acknowledge all the pig farmers in Nangabo Sub-county that participated in this study and gave us information on limitations to pig production on their farms. We also acknowledge the Sub county Veterinary officer, Nangabo Sub-County that provided us with the farmers' names and helped us locate and interview them. We would also like to acknowledge the Ministry of Education and Sports, Uganda (grant no. 08: U: 2581: EVE) for funding this study.

\section{Competing interests} interests.

The authors declare that they have no competing

\section{References}

1. Pérez, R. (1997) Feeding pigs in the tropics, Rome, Italy, FAO, Agriculture and Consumer protection

2. Williamson, C. S., Foster, R. K., Stanner, S. A. \& Buttriss, J. (2005) Red meat in the diet. Nutr Bul, 30, 323-355.

3. WHO (2010) Global Database on Child Growth and Malnutrition. WHO child growth standards. Geneva.

4. Lekule, F. P. \& Kyvsgaard, N. C. (2003) Improving pig husbandry in tropical resource-poor communities and its potential to reduce risk of porcine cysticercosis. Acta Trop, 87, 111-7.

5. UBOS (2008) A summary report of the national livestock census.Ministry of Agriculture Animal Industry and Fisheries, Entebbe, Uganda. In Anonymus (eds.) Kampala.

6. UBOS (2002) Uganda Population and Housing Census. IN SCHELLING, E. (Ed.) Kampala, Uganda.

7. UBOS (2010) Statistical abstract. Kampala, Uganda Bureau of Statistics.

8. Ajala, M. K. (2003) Economics of swine production in Ajama's local government area of Kaduna state, Nigeria. Trop JAnim Sci 6, 53-62.

9. Roepstorff, A., Mejer, H., Nejsum, P. \& Thamsborg, S. M. (2011) Helminth parasites in pigs: new challenges in pig production and current research highlights. Vet Parasitol, 180, 72-81.

10. Kimman, T. G., Cornelissen, L. A., Moormann, R. J., Rebel, J. M. \& Stockhofe-Zurwieden, N. (2009) Challenges for porcine reproductive and respiratory syndrome virus (PRRSV) vaccinology. Vaccine, 27, 3704-18.

11. Costard, S., Wieland, B., De Glanville, W., Jori, F., Rowlands, R., Vosloo, W., Roger, F., Pfeiffer, D. U. \& Dixon, L. K. (2009) African swine fever: how can global spread be prevented? Philos Trans $R$ Soc Lond B Biol Sci, 364, 2683-96.

12. Kagira, J. M., Kanyari, P. W., Maingi, N., Githigia, S. M., Ng'ang'a, J. C. \& Karuga, J. W. (2010) Characteristics of the smallholder free-range pig production system in western Kenya. Trop Anim Health Prod, 42, 865-73.

13. NAADS (2000) Master document of the NAADS task force and joint donor group Kampala, Ministry of Agriculture Animal Industry and Fisheries.

14. Mutua, F., Arimi, S., Ogara, W., Dewey, C. \& Schelling, E. (2010) Farmer perceptions on indigenous pig farming in Kakamega District, Western Kenya. Nordic JAfr Stud 19,43-57.

$* * * * * * * *$ 